\title{
Development and Evaluation of Solar-Powered Instrument for Hydroponic System in Limapuluh Kota, Indonesia
}

\author{
Perdana Putera ${ }^{\#}$, Sri Aulia Novita ${ }^{\#}$ Indra Laksmana ${ }^{\#}$, Muhammad Imran Hamid", Syafii* \\ \# Agricultural Machine and Equipment Department, Agricultural Polytechnic of Payakumbuh, Tanjung Pati, 50 Kota,26271, Indonesia \\ E-mail: perdana@politanipyk.ac.id
}

* Electrical Engineering Department, Andalas University, Limau Manis, Padang, 25163, Indonesia

E-mail:imrandgmasse@yahoo.com

\begin{abstract}
This solar-powered instrument utilized in plant cultivation in hydroponic system was developed to minimize operational cost, to maintain continuity of electrical source and to release dependency from electric utility. The instrument consist of solar tracker to adjust photovoltaic panel position, aquarium pump to distribute the nutrition, humidity and temperature meter to measure humidity and temperature, respectively. To support the function of this instrument 40 watt energy should be provided per hour in average. Following power measurement conducted in 50 Kota, 200WP of solar panel will produce roughly 70 watt at peak hour. The solar energy is stored to a couple of 100AH deep cycle battery, Arduino board microcontroller as brain of the system plays roles to control de motor and timer and to calculate data signal from RTC, humidity and temperature sensor. The data are then sent to LCD matrix $2 \times 16$ which will display the measurement. This instrument is expected to be used by hydroponics farmer in remote area.
\end{abstract}

Keywords - Solar-powered instrument; Hydroponics system; Arduino

\section{INTRODUCTION}

Decreasing of land area causes conventional agricultural system become uncompetitive because of price of land is rising day after day. Hydroponic agriculture cultivation technology system provides an alternative way for farmers who have a narrow field or just have a yard to carry out agricultural business.

Hydroponics system has advantages such as: the density of plants per unit area doubled or land-saving; product quality (shape, size, flavour, colour, cleanliness or hygiene; planting is not depend on the season or time and can be adjusted in accordance with market needs. Hydroponic cultivation usually implemented at greenhouse to keep plant growth optimally and to protect from external elements such as pests, rainfall and climate change. In addition

Continuity of energy supply becomes a main problem of hydroponic cultivation because of its dependence on energy sources. Especially when using full controlled system with a number of equipment to be controlled such as sensors (temperature, $\mathrm{pH}$ ), controller and others require continuous electrical energy. The use of generators is not efficient due to the cost and pollution generated.

Utilization of solar cell as a renewable energy at housing or transportation this moment is considered as solution to reduce dependency to fossil energy. Its usage for agriculture machine and equipment still not popular since it is expensive initial investment compare to the benefit obtained so that farmers prefer a machines which use combustion engine.

Solar energy utilization in agricultural equipment, for long-term, as an energy source is very promising, especially used as a hybrid with other agricultural energy sources material ie, straw and husks.

The focus of the research was to manufacture of hydroponic system that used solar power as source of energy for the instrument. The prototype of this instrument can be utilized for farmers who are in remote areas and minimize operational costs in the hydroponic cultivation such as NFT system and others that require continuity of electrical power source. Other benefit is also to release dependence on the electric company. The design tool based on the computer simulations performed using Matlab and Pspice software

This research was conducted in kabupaten Limapuluh kota which located between $0^{\circ} 25^{\prime} 28,71^{\prime \prime}$ - (-) $0^{\circ} 22^{\prime} 14,52^{\prime \prime}$ longitude, between $100^{\circ} 15^{\prime} 44,10^{\prime \prime}-100^{\circ} 50^{\prime} 47,80^{\prime \prime}$ latitude. The land area is $3.354,30 \mathrm{~km}^{2}$. Lima Puluh Kota has a tropical climate. The rainfall in Lima Puluh Kota is significant, with precipitation even during the driest month. Base on Köppen and Geiger classification, this climate is classified as tropical rain forest climate (Af). The average 
annual temperature in Lima Puluh Kota is $26.7^{\circ} \mathrm{C}$. In a year, the average rainfall is $2353.7 \mathrm{~mm}$.

\section{DEVELOPMENT OF SOLAR-POWERED INSTRUMENT}

Solar powered instrument for the hydroponic system consist of solar cell, solar charge controller, battery, inverter, temperature and humidity sensor, solar tracker system and hydroponic system.

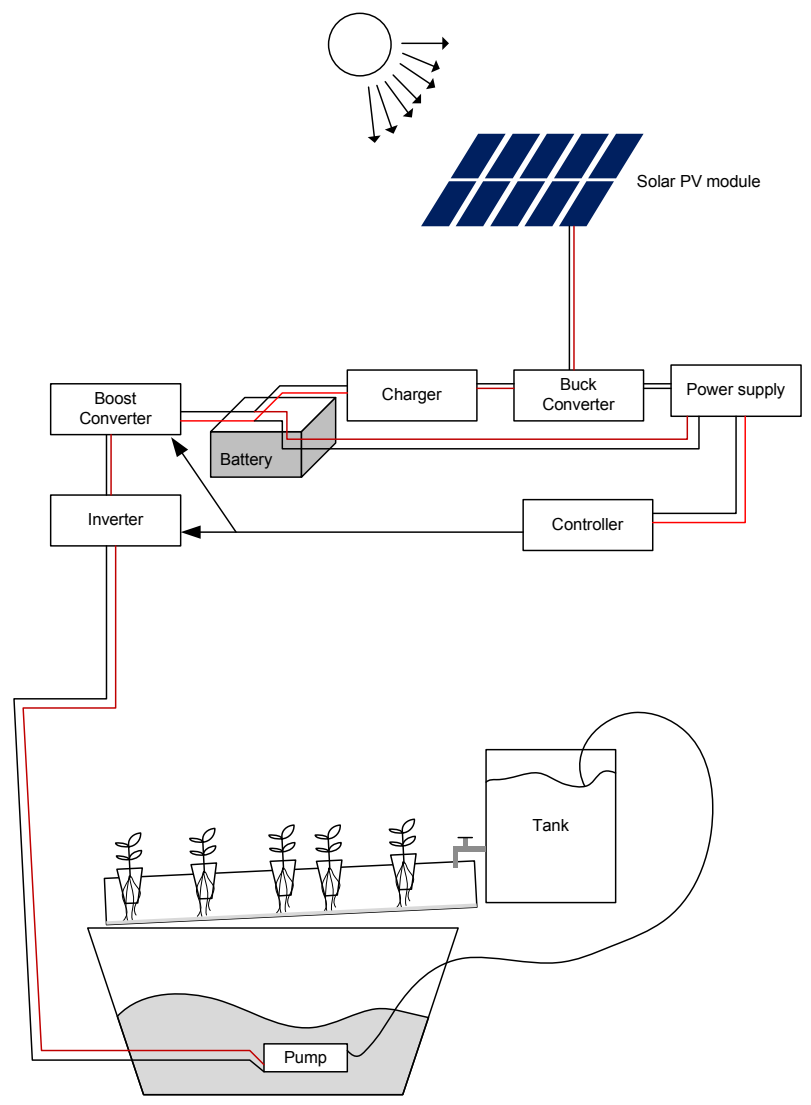

Fig. 1 solar-powered instrument for hydroponic system

\section{A. Hydroponic systems}

It can be seen from Fig1 that the system consist of reservoir as nutrient liquid container, a $25 \mathrm{~W}$ water pump was used to make the nutrient flows up to the tank this pump can draw approximately 13 litre per minute. One of the most popular hydroponic system is nutrient film technique (NFT). For this system, the flow speed of the nutrient liquid on growing media was about 1 litre per minute which is adjusted by using water tap. So the amount of time for pump to be on was less than 1 hour per day. A floating switch was placed in the tank to control electrical current to the pump. The availability of the tank is highly recommended to avoid the pump runs 24 hour per day. Overall system work is supported by power that came from solar panel module.

\section{B. Solar panel module}

A solar panel is made up of several photovoltaic solar cells to form higher power the Solar PV module production is continuously growing since it produce electricity without fuel consumption. The solar PV systems using modular technology so that it can be configured for varying capacity, ranging from watts to megawatts to fulfil either industrial or domestic energy needs.

Parameter of the solar PV used is as follows:

$\begin{array}{ll}\text { Maximum power } & : 100 \mathrm{~W} \\ \text { Maximum voltage } & : 17.5 \mathrm{~V} \\ \text { Maximum current } & : 5.71 \mathrm{~A} \\ \text { Open circuit voltage } & : 21 \mathrm{~V} \\ \text { Short circuit current } & : 6.4 \mathrm{~A}\end{array}$

In this case 2 solar PV module was used in parallel so that it will produce twice as much power and current as written above. In the commercial market, efficiency of solar cell can reach $18.3 \%$, for solar panel module, it would be slightly lower because of the blank space between solar cell arrays.[1]

\section{Solar Charge Controller and battery}

A solar charge controller has role as regulator of battery charging and prevention of overcharging which can shorten lifespan of battery. It also limits the electric current drawn from battery.

In this system, the energy output from the Solar PV systems is generally stored in a couple $100 \mathrm{AH}$ batteries. If only the system gives power to the $25 \mathrm{~W}$ water pump. It is assuming the system can keep autonomy run until 4 days continuously by considering depth of discharge only $50 \%$.

\section{Inverter}

Inverter is used to convert DC current into AC current. $\mathrm{AC}$ current from inverter may appear in: square and quasisquare wave, multilevel and sine wave. Fig 2 shows how the inverter wave form is made.

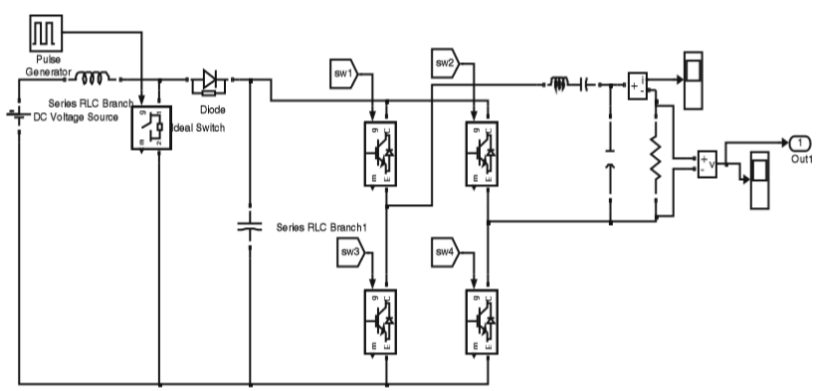

Fig. 2 boost converter and single phase inverter [1]

Basic form of inverter is the square wave but this type of inverter is not recommended because it has poor quality compare to multi-level inverter and sine inverter. The Multilevel inverter uses low frequency and the sine wave inverter is formed from high switching frequency. The first is suitable for high power because it is more efficient and robust, and the latter, is more for medium and low power applicaton.This high frequency inverters is far cheaper. By considering this, for small-solar power instrument used in this hydroponic system, a $500 \mathrm{~W}$ sine wave is installed to support AC pump work. 


\section{E. Other instruments}

1) Temperature-humidity and display

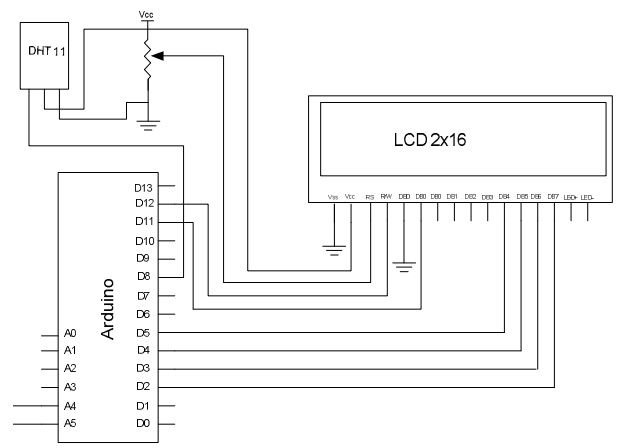

Fig 3. Electrical connection between Arduino, humidity-temperature sensor and Liquid Crystal Display

Temperature-humidity sensor used was DHT 11. This sensor detected the humidity and the temperature in analogue form. After been changed into digital signal in ADC in microcontroller, this data was converted into value that can be shown in LCD.

\section{2) DC Motor dan RTC}

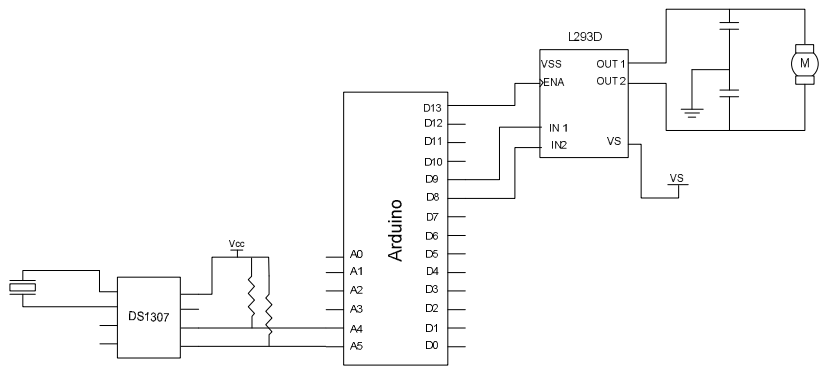

Fig 4. Electrical connection between Arduino, RTC and slow speed DC Motor

Real Time Clock (RTC) was used to keep track of the current time while DC motor was used to drive position of solar panel. The difficulty of using de motor was to adjust the position even for the slow speed dc motor.

\section{SIMULATION OF THE SYSTEM}

\section{A. MATLAB Simulation of Solar PV Module}

Solar PV modul was simulated base on parameter of PV modul

$$
\begin{aligned}
& I=I_{p v}-I_{o}\left[\exp \left(\frac{V+I R_{s}}{a V_{T}}\right)-1\right]-\frac{V+I R_{s}}{F_{s i t}} \\
& V_{T}=\frac{N_{s} R T}{q} \\
& I_{p v}=\frac{G}{G_{n}}\left[I_{p v n}+K_{I}\left(T-T_{n}\right)\right] \\
& I_{o}=I_{o n}\left(\frac{T}{T_{n}}\right)^{3} \exp \left[\frac{q E_{g}}{a k}\left(\frac{1}{T_{n}}-\frac{1}{T}\right)\right] \\
& I_{o n}-\frac{I_{s c n}}{\exp \left(V_{\text {ocn }} / a V_{T n}\right)-1}
\end{aligned}
$$

For simulation of solar panel in Standar Test Condition, it is derived as figure 5 and figure 6 . It can be seen

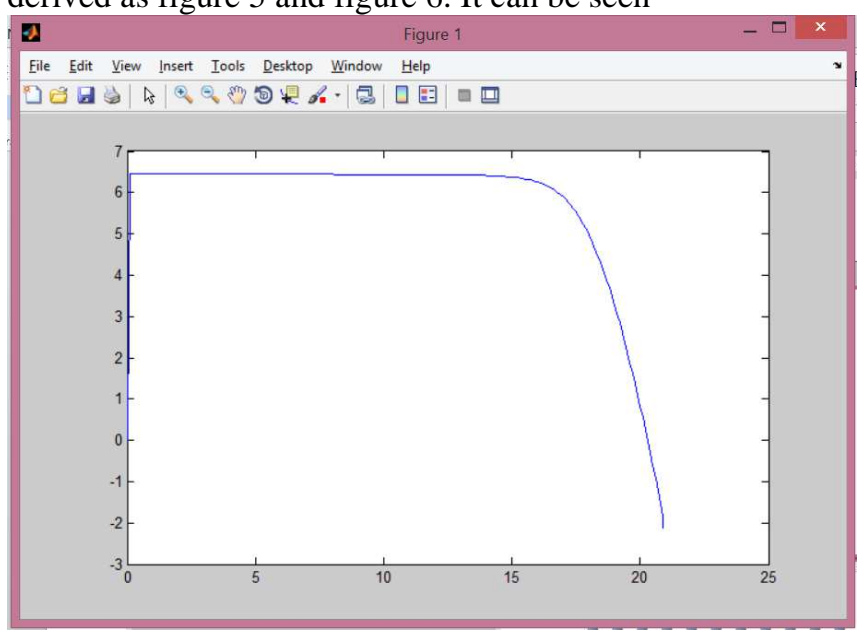

Fig 5. V-I Relationship

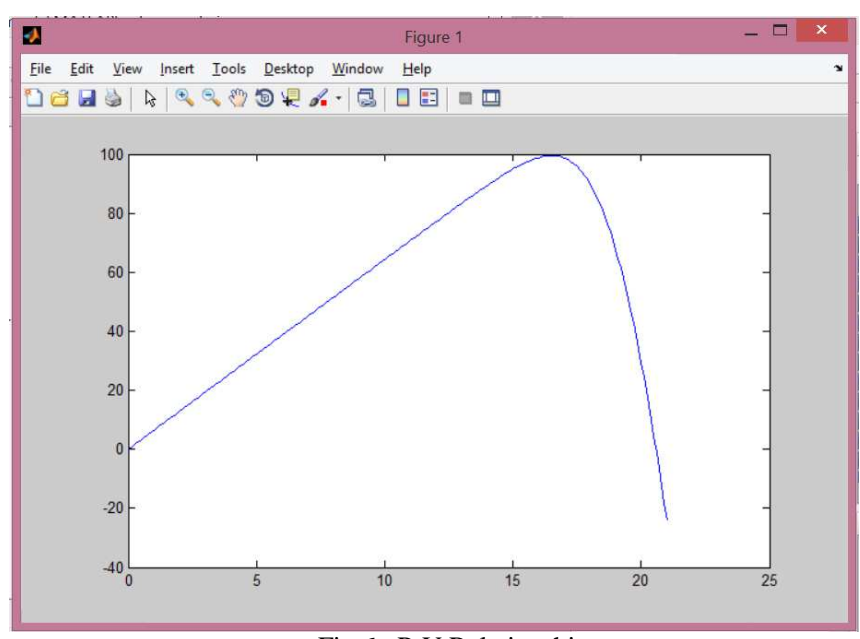

Fig 6. P-V Relationship

\section{B. PSpice simulation of boost converter and inverter}

The dc-dc converters are widely used in regulated switch mode dc power supplies and in dc motor drive applications. Often the input to these converters is an unregulated dc voltage and the average dc output voltage must be controlled to equal a desired level. For boost (step up) converter, As the name implies, the output voltage is always greater than the input voltage.

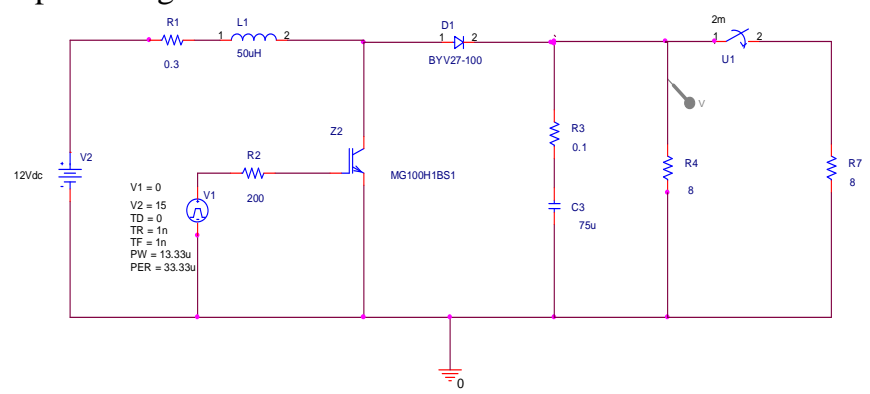

Fig 7. The switch model of boost converter

For the switch model in Figure (1), when the switch is on, the diode is reversed biased, thus isolating the output stage. The input supplies energy to the inductor. When the switch is off, the output stage receives energy from the inductor as 
well as from the input. In the steady state analysis, the output filter capacitor is chosen to be large to ensure a constant output voltage.

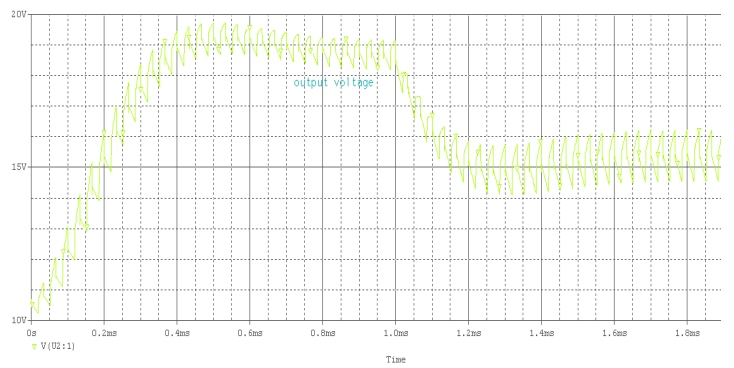

Fig. 8 output voltage using switch model

We can see from figure 8 that the output voltage in the steady state has for half load is higher than full load.

Figure 9 shows the schematic circuit for the PWM inverter with filtering implementation. At the input part, Analogue Behavioral Modeling (ABM) is used instead of the comparator because of $\mathrm{ABM}$ can handle higher frequency range rather than comparator. The PWM inverter includes PWM and a full bridge inverter. PWM is produced by having a sinusoidal source as the modulating waveform and a voltage pulse source as the carrier waveform. These two waveforms are compared using an ABM model as said earlier which will then produce PWM pulses. These pulses will be sent to the four IGBTs (inverter) as their switching signal. The switching scheme that used in this design is bipolar type. The characteristic of the switching signal will produce a sinusoidal waveform at the output of the inverter. This signal is then filtered by a LC filter to produce a pure ac waveform. The design of the filter is based on the location of the first harmonic that exists at the output of the inverter.

In order to obtain a $240 \mathrm{Vrms}$ at the output, in an ABM or analog behavioral modeling is used instead of transformer to step up the voltage

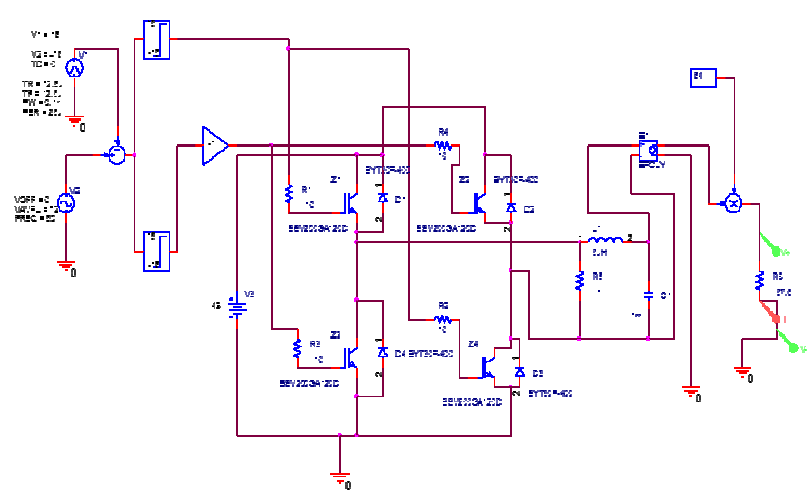

Fig.9. Schematic circuit for the PWM inverter

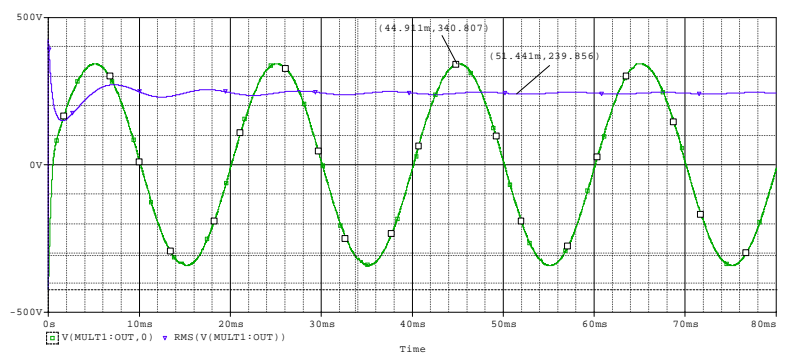

Fig.10. Output voltage of the PWM inverter and its RMS value

\section{IMPLEMENTATION OF SOLAR-POWERED INSTRUMENT IN LIMAPULUH KOTA}

Point where this research conducted is located at $00^{\circ} 10^{\prime}$ 09.5" S Latitude and $100^{\circ} 39^{\prime} 52.2^{\prime \prime}$ E Longitude which has altitude $512 \mathrm{~m}$.

TABLE I

MONTHLY WEATHER AVERAGE SUMMARY

\begin{tabular}{|l|r|r|r|r|c|}
\hline Month & $\begin{array}{c}\text { Precip } \\
\text { itation } \\
(\mathbf{m m})\end{array}$ & $\begin{array}{c}\text { Wind } \\
\text { Speed } \\
\mathbf{( k m / h )}\end{array}$ & $\begin{array}{c}\text { Humidi } \\
\text { ty (\%) }\end{array}$ & $\begin{array}{c}\text { Average } \\
\text { Tempera } \\
\left.\text { ture } \mathbf{~}^{\mathbf{0}} \mathbf{C}\right)\end{array}$ & $\begin{array}{c}\text { Solar } \\
\text { radiation } \\
\mathbf{k W H / m 2} \\
\text { /day) }\end{array}$ \\
\hline January & 236.3 & 9 & 83 & 26.4 & 37.4 \\
\hline February & 214.3 & 9 & 82.6 & 26.7 & 4.06 \\
\hline March & 229.8 & 8.6 & 83.3 & 27.3 & 4.40 \\
\hline April & 257.7 & 8.6 & 84 & 27.3 & 4.41 \\
\hline May & 156.4 & 8.3 & 83.7 & 27.3 & 4.22 \\
\hline June & 124.6 & 8.6 & 82.7 & 26.6 & 4.38 \\
\hline July & 112.4 & 9 & 83.1 & 26.4 & 4.34 \\
\hline August & 135.3 & 8.6 & 82.8 & 26.4 & 4.34 \\
\hline September & 186.9 & 9 & 83.6 & 26.5 & 4.21 \\
\hline October & 196.2 & 8.6 & 83.8 & 26.7 & 3.91 \\
\hline November & 240.7 & 9 & 84.7 & 26.8 & 3.65 \\
\hline December & 263.1 & 9.4 & 84 & 26.5 & 3.45 \\
\hline Source: Weather
\end{tabular}

Source: Weatherbase.com and pvwatt.com

Average daily solar radiation is $4.09 \mathrm{kWH} / \mathrm{m}^{2} /$ day. By using this radiation $200 \mathrm{WP}$ solar panel produced about 224 kWH per year or 613 Watt Hour per day. Most of aquarium pump (usually used for hydroponic system is below $50 \mathrm{~V}$. so that by assuming the inverter and motor is $50 \%$, a 25 watt aquarium pump was used. But from 1 month observation at the point, maximum power produced by the system was only about 380 watt per day. This might happened because of smoke from forest fires which caused solar radiation diffused.

\section{CONCLUSIONS}

A couple of standard 100 watt PV panel produced about 600 watt hour per day in kabupaten 50 kota by not taking unnatural parameter like smoke into account. The system could only handle 25 water pump.

\section{NOMENCLATURE}

$\begin{array}{lll}\mathrm{I} & \text { Current } & \mathrm{A} \\ \mathrm{V} & \text { Voltage } & \mathrm{V} \\ \mathrm{K} & \text { Boltzman Constant } & \mathrm{J} \mathrm{K}^{-1} \\ \mathrm{G} & \text { Irradiance } & \mathrm{Wm}^{-2} \\ \mathrm{~T} & \text { Temperature } & \mathrm{K} \\ \mathrm{q} & \text { Charge of electron } & \mathrm{C}\end{array}$

\section{Subscripts}

sen nominal short circuit

ocn nominal open circuit

$\mathrm{n}$ nominal

\section{ACKNOWLEDGMENT}

We would like to thank to Directorate General of Higher Education for funding the research through Pekerti Scheme Grant. 


\section{REFERENCES}

[1] S. Sumathi L. Ashok Kumar P. Surekha, Solar PV and Wind Energy Conversion Systems, Springer 2015

[2] Otto, Tyler N., Comparative study of grid connected photovoltaic arrays. San Diego State University, 2009

[3] J Dooren bos. Fao Irrigation and Drainage Paper. Food and Agriculture Organization Of the united nation 1977
[4] Akrem, Boost converter, Universiti Teknologi Malaysia, 2009

[5] 2015 The pvwatt website. [Online]. Available: http://pvwatts.nrel.gov

[6] 2015The weather website. [Online]. http://www.weatherbase.com
Available: 